\title{
Influence of Temperature Regime on Nickel Kinetics in Two Alluvial Soils from Arid Region
}

\author{
Sahar M. Ismail ${ }^{1}$, Sherine M. Shehata ${ }^{1}$ and Alaa M. Zaghloul ${ }^{2}$
}

\begin{abstract}
The effect of soil temperature on Nickel $\left(\mathrm{Ni}^{2+}\right)$ adsorption/desorption using a kinetics approach was studied in two Egyptian surface alluvial soil samples (0-30 cm) varying in their clay content and other related properties and collected from El-Menoufya Governorate, Egypt. The kinetics of $\mathrm{Ni}^{2+}$ adsorption, as well as desorption, were determined at three temperature regimes i.e. 5,28 , and $50^{\circ} \mathrm{C}$ for each soil using the batch technique. The calculated values of energies of activation for adsorption $\left(K_{a}\right)$ ranged between 5.21 - 5.34 for Soil $1\left(S_{1}\right)$ and 5.32 - $6.23 \mathrm{kcal}$ mol-1 for Soil $2\left(\mathrm{~S}_{2}\right)$, respectively. The respective values of Ed were 2.44 - 3.71 and 2.42 - 3.57 kcal mol-1. Results also showed that the Ed values were greater than the Ea values in both soils; implying further energy has been required to desorb $\mathrm{Ni}^{2+}$ than to release for both soils. Thermodynamic variables have been calculated by Gibbs' and Eyring's equations. The free energy of $\mathrm{Ni}^{2+}$ adsorption $\left(\Delta \mathbf{G}^{\circ}\right)$ were negative values (ranging between 0.234 and -0.411 in $S_{1}$ and from - 0.357 to -0.436 in $S_{2}$ cal mol $^{-1}$ ), meaning decrease in $\Delta G$ values with increasing the temperature. For $\mathrm{Ni}^{2+}$ desorption $(\Delta \mathrm{Gd})$, The free energy of activation values was higher than those for $\mathrm{Ni}^{2+}$ adsorption $(\Delta \mathbf{G a})$, suggesting that it is necessary to release $\mathrm{Ni}^{2+}$ more free energy than to adsorb it. The good agreement of calculated $\mathrm{AG}^{\circ}$ from Gibbs' theory reaction denoting that the thermodynamic constants could be determined using the kinetic parameters. The enthalpy $(\Delta \mathbf{H})$ parameter numerical values were exothermic and showed a greater binding of $\mathrm{Ni2}+$ ions in $\mathrm{S}_{2}$ than in $\mathrm{S}_{1}$ according to the distinction between external surfaces to interlayer surfaces charge ratio. The enthalpy of activation $(\Delta \mathrm{H})$ values in both soils were -2.127 and $-0.497 \mathrm{cal} \mathrm{mol}^{-1}$ in $S_{1}$ and $S_{2}$ respectively, proposing the heat energy needed to overcome the $\mathrm{Ni}^{2+}$ desorption in $\mathrm{S}_{2}$ as compared to $\mathrm{S}_{1}$.
\end{abstract} Nickel.

Keywords: Alluvial soils, Thermodynamics, Kinetics,

\section{INTRODUCTION}

Soil contamination by inorganic pollutants like Ni2+ was originally noticed in soils, but in modern time it has become a significant problem due to increasing anthropogenic activities. Nickel is an important animal nutrient and important element for plants in trace concentration (Marschner, 1995 and Kabata-Pendias,
2011). Unlike other heavy metals, Nickel is safe for human consumption up to $8 \mathrm{mg}$ could be consumed on a daily basis without any health risks. Nickel is an essential element as trace quantities for human life as a part of vitamin B-12, it also used as a treatment for anaemia, because it causes red blood cells production. The nickel in the soil as a pollutant is low compared to other heavy metals, but when $\mathrm{Ni} 2+$ combines with $\mathrm{Cu}$ or $\mathrm{Zn}$, increase its toxicity through synergistic mechanism (Saber et al., 2012). Exposure to high levels of Ni can cause health hazards where its effects on the lungs and wheezing have been found in workers who breathed significant levels of $\mathrm{Ni}$ by the air. However, as with other inorganic pollutants, increasing $\mathrm{Ni}$ accumulation in soil ecosystems can have negative effects on the cultivated plants, animals and microorganisms, which increase the risky effects of $\mathrm{Ni}$ in soils (Thakali et al., 2006 and Antoniadis et al., 2017a, b). The natural geochemical processes like increasingly frequent anthropogenic activities, including industrial operations (mining, smelting, electroplating, stealing), weathering of rocks, metallic products (alloy, textile, pigment, motor vehicles, chemical, aircraft paint), high application of fertilizers and pesticides, waste combustion and sewage sludge spreading in agriculture have a significantly increased the $\mathrm{Ni}$ contamination in soil (Gimeno-García et al., 1996; Kopittke et al., 2007; Rajkumar and Freitas, 2008b). Recently, due to its concentration of more than $26,000 \mathrm{mg} \mathrm{kg}^{-1}$ in heavy metals polluted soils and $0.2 \mathrm{mg} \mathrm{L}^{-1}$ in contaminated waters, $\mathrm{Ni}$ becomes a severe issue; these values are much greater than those observed in cleaned areas $(\mathrm{Ma}$ and Hooda, 2010). Increasing of $\mathrm{Ni}$ concentrations in soils as a possibly pollutant can induce negative effects on soil function examples beside significant mobilityrelated environmental issues and transfer to the food chains. Pollution of soils by Ni could, therefore, be a worldwide environmental problem and protection issues should be applied in the environment (Kabata Pendias, 2011 and Yusuf et al., 2011). The impact of temperature on soil pollutant reaction rates is well recognized and important in understanding the pollutant distribution mechanisms. Although there is voluminous literature of

\footnotetext{
DOI: 10.21608/ASEJAIQJSAE.2019.39315

${ }^{1-}$ Soil physics and chemistry Department, Water Resources and Desert Soils Division, Desert Research Center, 1 El-Mataria St., Cairo, Egypt.

${ }^{2}$ Soils and Water Use Dept., Agricultural and Biological Research Division,

National Research Center, 33 El-Behouth St., Dokki, Giza, Egypt. National Research Centre

Received May 22, 2019, Accepted June 29, 2019
} 
$\mathrm{Ni}$ reactions in soils, no available data regarding the thermodynamic parameters (enthalpy and entropy) and their effects on $\mathrm{Ni}$ adsorption in soils of arid regions. The aim of this study is to investigate the effect of different temperatures regime on Ni kinetics in alluvial soils of the arid region.

\section{MATERIALS AND METHODS}

\section{Location and characteristics of soil}

Two surface alluvial soil samples $\left(S_{1} \& S_{2}\right)$ were collected from west east middle Delta (El-Menoufya Governorate). The collected samples varied in their clay contents. The studied soils were analyzed to their physicochemical and mineralogical properties according to standard methods described by Sparks, (1995) and reported in Table (1). Soil samples were air dried and crushed to pass through a 2-mm sieve and prepared for application of the different treatments.

Kinetics of $\mathrm{Ni}$ adsorption for the studied soils as influenced by temperature regimes:

Kinetic experiments for $\mathrm{Ni}$ sorption and desorption were carried out using Batch method, explanation of the technique was documented by Nadia Gad et al. (2013). Soil samples were shaken in a water bath at $5 \pm 1{ }^{\circ} \mathrm{C}, 28$ $\pm 1^{\circ} \mathrm{C}$, and $50 \pm 1{ }^{\circ} \mathrm{C}$ for 48 hours. The equilibration period was 48 hours for adsorption and desorption of $\mathrm{Ni}$ by the selected soils assigned on the basis of previous experiments with shaking period of 12, 24, 36, 48 hours. According to the literature, the equilibrium for nickel adsorption is reached within 24 hours (Cavallaro and McBride, 1978). After the equilibrium period, the soil samples were centrifuged at $15000 \mathrm{rpm}$ for 10 minutes and $\mathrm{Ni}$ was determined by using an ICP. A volume of deionized water equal to that of the adsorption solution was added to the remaining solid and samples were shaken for 48 hours at $5 \pm 1{ }^{\circ} \mathrm{C}, 28 \pm 1{ }^{\circ} \mathrm{C}$, and $50 \pm{ }^{\circ} \mathrm{C}$. After centrifugation $\mathrm{Ni}$ desorbed was also measured using ICP. It should be noted that the $\mathrm{pH}$ reached at the equilibrium for the adsorption varied from 4.9 to 5.6, while for the adsorption, it was the same for all samples. Adsorption and desorption rate constants were calculated using the first-order equations. The first-order kinetic model provided, in terms of $\mathrm{R}^{2}$ and standard error (SE), the best fits of the data and apparent rate constants, ka, were calculated. Energies of activation values for adsorption and desorption were calculated by the Arrhenius and van't Hoff equations. The $\Delta \mathrm{G}, \Delta \mathrm{H}$, and $\Delta \mathrm{S}$ for $\mathrm{Ni}$ exchange were calculated using Eyring's absolute reaction rate theory as mention by Nadia Gad et al., 2013). The adsorption of $\mathrm{Ni}$ and desorption from used soils were confirmed to the first-order kinetic model. The rate coefficients of $\mathrm{Ni}$ adsorption and desorption ( $k a$ 'and $\mathrm{kd}^{\prime}$, respectively) will be calculated from the first-order kinetic model as derived below.

\section{Apparent Adsorption Rate Coefficient ( $\left.k^{\prime}{ }^{\prime}\right)$}

Adsorption rate was calculated according to the following equation:

$$
\log \left(1-\mathrm{K} / \mathrm{K}_{\infty}\right)=\mathrm{k}_{\mathrm{a}} \cdot \mathrm{t}
$$

Where:

$\mathrm{K}=$ amount of $\mathrm{Ni}$ adsorbed on the soil at equilibrium $(\mathrm{mg} / \mathrm{kg})$.

$\mathrm{k}_{\mathrm{a}}{ }^{ }=$adsorption of $\mathrm{Ni}$ at time $\mathrm{t}$ divided by 2.303

\section{Desorption Rate Coefficient ( $\left.\mathbf{k}_{\mathbf{d}}{ }^{\prime}\right)$}

$$
\log \left(\mathrm{K}_{\mathrm{t}} / \mathrm{k}_{0}\right)=\mathrm{k}_{\mathrm{d}}{ }_{\mathrm{t}} \mathrm{t}
$$

Where

$$
\begin{aligned}
& \mathrm{K}_{\mathrm{t}}=\text { amount of Ni desorption at time } \mathrm{t}(\mathrm{mg} / \mathrm{kg}) \\
& \mathrm{K}^{\prime}{ }_{\mathrm{d}}=\text { desorption rate coefficient }
\end{aligned}
$$

\section{Thermodynamic parameters}

Calculation of thermodynamic parameters of $\mathrm{Ni}$ exchange was done by Gibbs and Eyring's reaction rate equations. The variation between the adsorbed and desorbed of $\mathrm{Ni}$ was controlled by several factors that limited the availability of this pollutant, indicating partial reversibility, subsequently the following relationship and could be written according to Nadia Gad et al., 2013 as:

$$
\mathbf{K}_{\mathbf{a}} / \mathbf{k}^{\prime}{ }_{\mathbf{d}}=\mathbf{K}
$$

Where $\mathrm{K}$ is the apparent equilibrium constant

\section{Free energy of activation $\Delta \mathbf{G}$}

The free energy for Ni exchange $\left(\Delta \mathrm{G}^{0}\right)$ can be obtained,

$$
\begin{gathered}
\Delta G^{0}=-R T \ln K \\
\text { Or } \\
\left.\Delta G^{0}+-R T \ln \left(k_{a}^{\backslash_{a}} / k_{d}\right\rfloor_{d}\right)
\end{gathered}
$$

The entropy for $\mathrm{Ni}$ exchange $\left(\Delta \mathrm{S}^{0}\right)$ could be determined by the relation mentioned in the work of Nadia Gad et al., 2013 as:

$$
\Delta \mathbf{S}^{0}=\left(\Delta \mathbf{H}^{\circ}-\Delta \mathbf{G}^{\circ}\right) / \mathbf{T}
$$

Where

$$
\begin{aligned}
\Delta \mathrm{H} & =\text { enthalpy of activation, } \\
\Delta \mathrm{S} & =\text { entropy of activation } \\
\mathrm{T} & =\text { absolute temperature }, \text { and }
\end{aligned}
$$

Since $\Delta \mathrm{H}_{\mathrm{a}}$ is found from the following relationship:

$$
\Delta \mathbf{H}_{\mathbf{a}}=\mathbf{E}_{\mathbf{a}}-\mathbf{R T}
$$

The $\Delta \mathrm{G}_{\mathrm{a}}$ can be measured using this formula:

$$
\Delta \mathbf{G}_{\mathbf{a}}=\Delta \mathbf{H}_{\mathbf{a}}-\mathbf{T} \boldsymbol{\Delta} \mathbf{S}
$$

Analogous expressions for the reverse reaction can be achieved by using $\mathrm{k}_{\mathrm{d}}$ and $\mathrm{E}_{\mathrm{d}}$ estimated for the desorption process. 
Table 1. Some physicochemical characterization of used soils according to Standard Methods of Sparks (1995)

\begin{tabular}{|c|c|c|c|c|c|c|c|c|c|}
\hline $\begin{array}{r}\text { Soil } \\
\text { No. }\end{array}$ & $\begin{array}{r}\text { Depth } \\
(\mathbf{c m})\end{array}$ & $\begin{array}{c}\text { EC } \\
\mathbf{d S m}^{-1}\end{array}$ & pH & $\begin{array}{l}\text { OM } \\
(\%)\end{array}$ & $\begin{array}{c}\text { Clay } \\
\text { Cont. } \\
\%\end{array}$ & $\begin{array}{c}\text { Amorphous } \\
\mathrm{Fe}_{2} \mathrm{O}_{3} \\
\text { ppm }\end{array}$ & $\begin{array}{c}\text { Total } \\
\mathrm{CaCO}_{3} \\
\%\end{array}$ & $\begin{array}{c}\text { Available } \\
\text { Ni } \\
\text { ppm }\end{array}$ & $\begin{array}{c}\text { Surface } \\
\text { area } \\
\mathbf{m}^{2} / \mathbf{g}\end{array}$ \\
\hline $\begin{array}{l}\text { Soil } 1 \\
\text { (S1) }\end{array}$ & $0-30$ & 0.5 & 7.94 & 1.39 & 28.5 & 0.39 & 3.31 & 1.44 & 131 \\
\hline $\begin{array}{l}\text { Soil } 2 \\
\text { (S2) }\end{array}$ & $0-30$ & 0.8 & 8.12 & 1.72 & 41.6 & 0.22 & 4.5 & 1.77 & 200 \\
\hline
\end{tabular}

\section{RESULTS AND DISCUSSION}

\section{Kinetics of Ni adsorption and desorption from used} soils as influenced by temperature regime:

The kinetics of $\mathrm{Ni}$ adsorption and desorption from the used soils confirmed to first-order kinetic model at various temperatures tested by having high $\mathrm{R}^{2}$ and low SE. The linear straight-line of Ni sorption in the soil 1 $\left(\mathrm{S}_{1}\right)$ and soil $2\left(\mathrm{~S}_{2}\right)$ samples indicates to existence of the kinetic first-order model Figure (1).

Also, the kinetic results confirmed that Modified Freundlich and parabolic diffusion models gave high conformity to describe the kinetic data of the studied soils with linear relationships existing in both the adsorption and desorption experiments (Data not shown).

The low $\mathrm{Ni}$ exchange rate is associated the existence of clay mineral amounts in the used soils as shown in the soil characterizations represent in Table (1), showing a diffusion mechanism is controlled exchange (Sparks, et al., 1980; Nadia Gad and Zaghloul, 2007).

Effect of temperature regime applied on $\mathrm{Ni}$ adsorption and desorption Rate Coefficients:

Results in figure (2A) represent the impact of temperature regime on the rate of $\mathrm{Ni}$ adsorption and desorption. Data imply that increasing of temperature from $5^{\circ} \mathrm{C}$ to $28^{\circ} \mathrm{C}$ led to increasing the rate of adsorption from 5.14 to 5.21 and from 5.32 to $5.78 \mathrm{mg}$ $\mathrm{kg}-1 \mathrm{hr}-1$ in $S_{1}$ and $S_{2}$, respectively. Increasing the temperature to $50^{\circ} \mathrm{C}$ gave the highest values for both soils reached to 5.34 and $6.23 \mathrm{mg} \mathrm{kg}-1 \mathrm{hr}-1$ in $S_{1}$ and $S_{2}$ respectively. Increasing of the rate of adsorption in $\mathrm{S}_{2}$ compared to $S_{1}$ mainly due to increasing the clay content in $S_{2}$ and $S_{1}$ (41.6 and 28.5\%) respectively. Also, increasing of $\mathrm{OM}$ in $S_{2}$ compared to $S_{1}$ could be playing an important role in $\mathrm{Ni}$ retention in $\mathrm{S}_{2}$. Figure (2B) represents the rate of $\mathrm{Ni}$ desorption as affected by the same temperature regime. Results showed that the rate of desorption slightly varied between the two studied soils. Increasing the temperature regime from 5 to $28^{\circ} \mathrm{C}$ and $50^{\circ} \mathrm{C}$, increased the rate of desorption from 2.44 to $3.07,3.7 \mathrm{mg} \mathrm{kg}^{-1} \mathrm{hr}^{-1}$ and from 2.41 to 3.04 and $3.57 \mathrm{mg}$ $\mathrm{kg}^{-1} \mathrm{hr}^{-1}$. Hysteresis phenomena in natural clays have a significant impact on inorganic pollutants for both transport and bioavailability. Sorption and desorption of $\mathrm{Ni}$ in selected soils were significantly observed as depicted in figures 2A and 2B. Hysteresis is a condition in which the adsorption and desorption isotherms do not overlap (Strawn and Sparks, 1999).

Hysteresis phenomena were explained by many authors with different mechanisms including variability of the binding mechanism with time, chemical precipitation, micro-porous deformation and holding, movement and incorporation of the solute into the soil matrix (Weber \& Huang, 1998, McBride, 2000 and Sander et al., 2005). Pseudo-hysteresis phenomenon is associated to slow desorption kinetics, fail to reach the equilibrium before the starting of the desorption (McBride, 2000). One possible reason for slow desorption is that chemical adsorption processes generally need a much greater activation energy in the direction of desorption than adsorption, to separate the energetically very suitable bonds of the sorbate with the surface (McBride, 2000 and Apple \& Ma, 2002). 

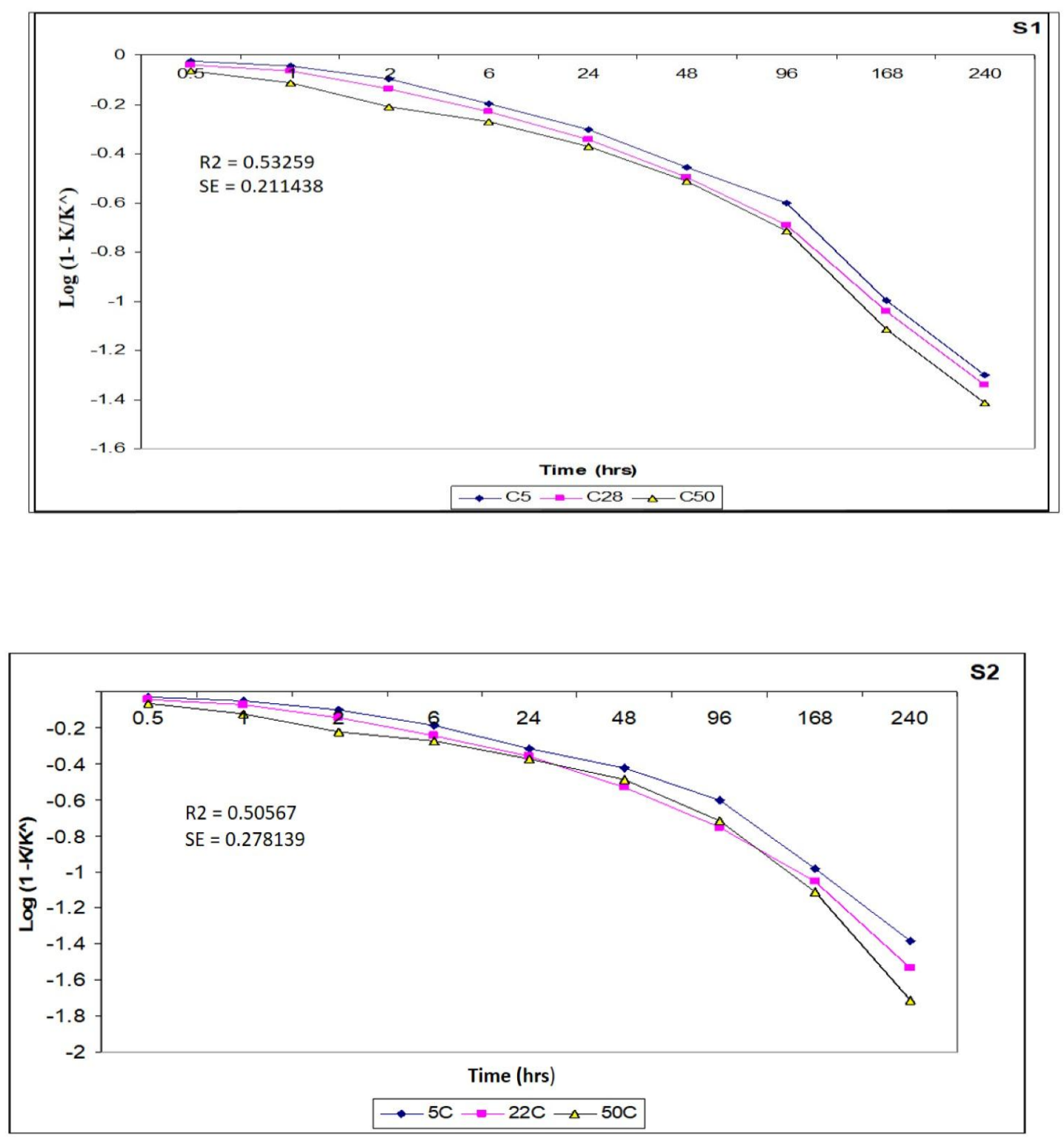

Figure 1. Kinetics of $\mathrm{Ni}$ adsorption for the selected soil samples as described by $\mathbf{1}^{\text {st }}$ order kinetic models at different temperature regime studied where $\mathrm{K}$, reflects the Ni quantity on the soil exchange sites after time $t$ of adsorption, and $\mathrm{K} \varphi$ indicates the quantity of $\mathrm{Ni}$ on the exchange sites at equilibrium. 
A

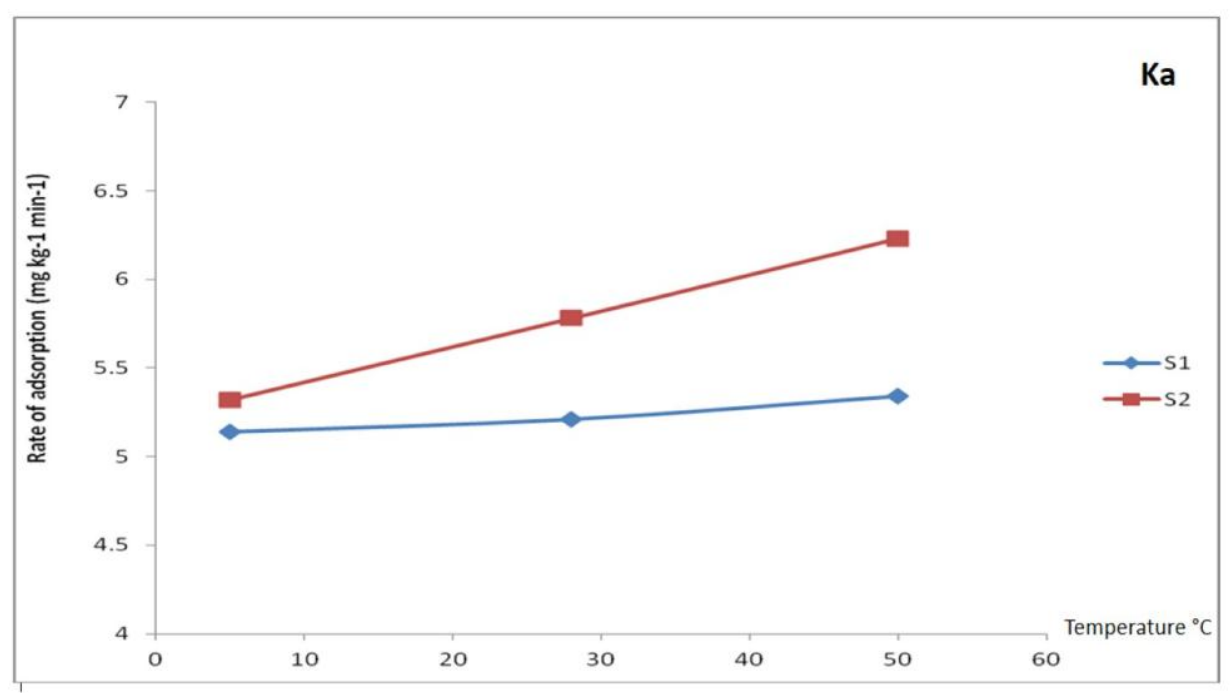

B

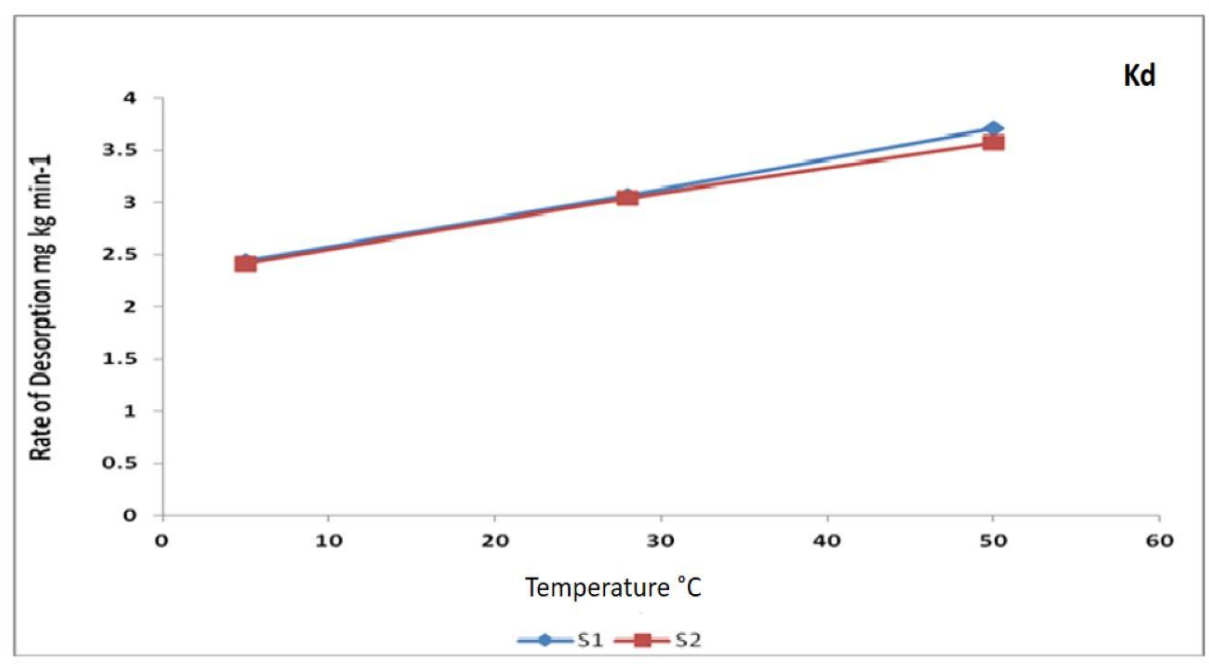

Fig.2. Impact of temperature regime of the rate of Ni adsorption (Ka) and desorption $\left(K_{d}\right)$ in the two studied soil samples 
Table 2. Rate parameters ( $k_{\mathrm{a}}$ and $\left.k_{d}\right)$ of $\mathrm{Ni}$ at three temperature regimes, energies of activation $\left(E_{\mathrm{a}}\right.$ and $\left.\mathbf{E}_{\mathrm{d}}\right)$, and thermodynamic parameters using $1^{\text {st }}$ order kinetic model exchange in two alluvial soils

\begin{tabular}{|c|c|c|c|c|c|c|c|}
\hline \multirow{2}{*}{$\begin{array}{c}\text { Temperature } \\
{ }^{\circ} \mathrm{C}\end{array}$} & $K_{a}$ & $K_{d}$ & \multirow{2}{*}{\multicolumn{2}{|c|}{$\frac{\mathbf{E}_{\mathbf{a}}}{\text { Kcal mol }^{-1}}$}} & \multirow{2}{*}{\multicolumn{2}{|c|}{$\begin{array}{cc}\Delta \mathbf{G} \quad \Delta \mathbf{H} \\
\mathrm{Cal} \mathrm{mol}^{-1}\end{array}$}} & \multirow{2}{*}{$\begin{array}{c}\Delta S \\
{\text { Cal } \text { mol }^{-1} \mathbf{k}^{-1}}^{\prime}\end{array}$} \\
\hline & \multicolumn{2}{|c|}{$\mathrm{mg} \mathrm{kg}^{-1} \mathrm{hr}^{-1}$} & & & & & \\
\hline 5 & 5.14 & 2.441 & \multicolumn{2}{|c|}{ S1 } & -0.411 & & -6.17 \\
\hline 28 & 5.21 & 3.072 & & & -0.316 & -2.127 & -6.02 \\
\hline \multirow[t]{2}{*}{50} & 5.34 & 3.709 & & & -0.234 & & -5.86 \\
\hline & & & 0.393 & 2.52 & & & \\
\hline \multicolumn{8}{|c|}{$\mathrm{S} 2$} \\
\hline 5 & 5.32 & 2.415 & & & -0.436 & & -0.219 \\
\hline 28 & 5.78 & 3.041 & & & -0.384 & -0.497 & -0.316 \\
\hline \multirow{2}{*}{50} & 6.23 & 3.572 & & & -0.357 & & -0.433 \\
\hline & & & 1.811 & 2.308 & & & \\
\hline
\end{tabular}

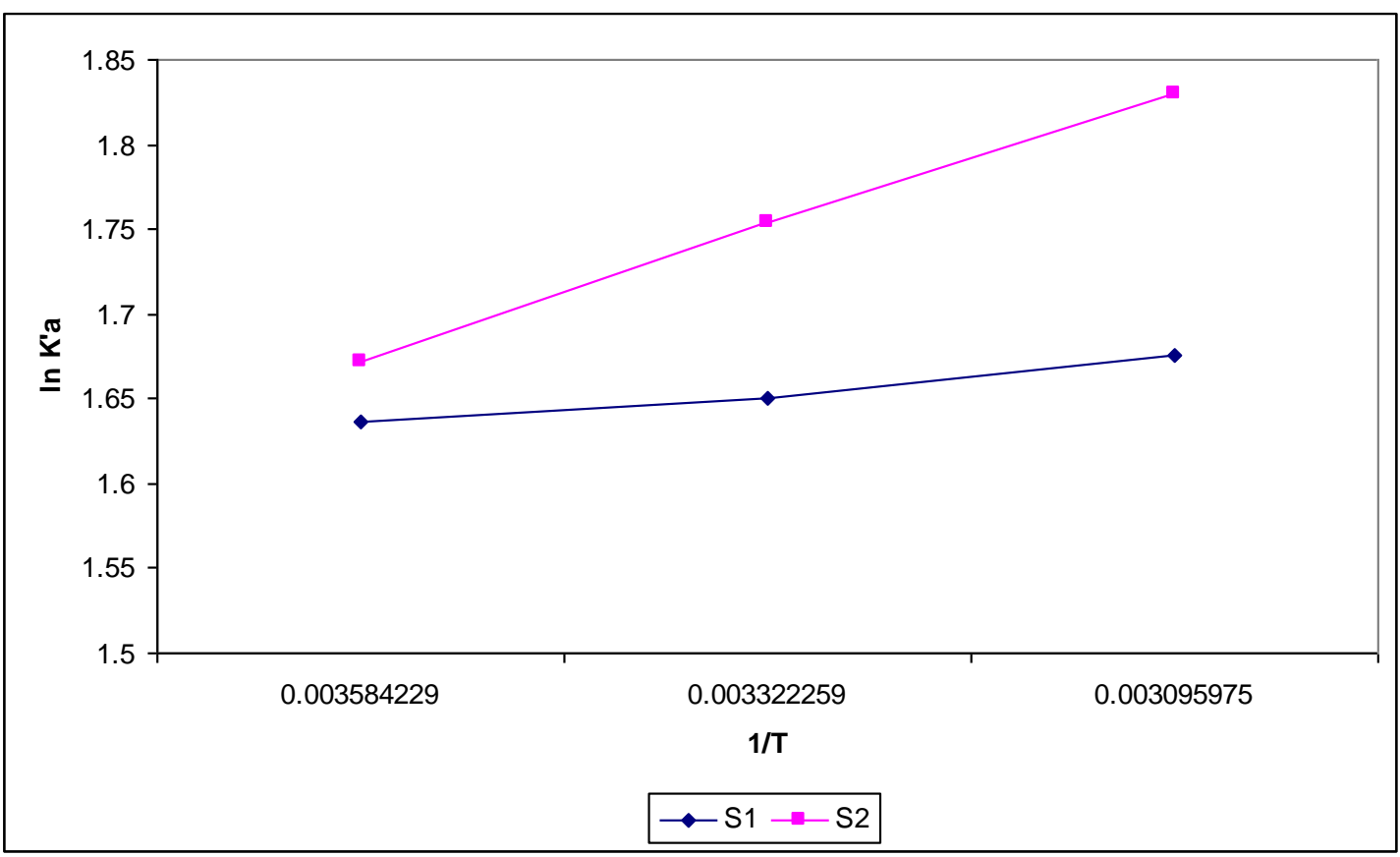

Fig. 3. The relation of $k^{\prime}$ a versus $1 / T$ for the two studied soil samples

The scale of the $E_{d}$ values is similar to those found by Mortland and Ellis, 1959 and Zaghloul, 2002, worth to mention that the same trend was observed in $\mathrm{S}_{2}$.

Thermodynamic Parameters of Ni Exchange in soil systems:

The $\Delta \mathrm{G}$ values for exchange of $\mathrm{Ni}$ were negative and increased with increasing the temperature as shown in table 2, they are similar with those discovered by Zaghloul, (2002) and Kuo, and Lotse, (1974). The more negative values for $\Delta G$ in $S_{2}$ than in the $S 1$ could be related to increasing of per cent of clay in the soil which gave driving force for the entire process in the high clay content soil as shown in Table (1). This driving force for all process makes $\mathrm{Ni}$ reaction easier with less diffuse resistance. The $\Delta \mathrm{H}$ values are shown in Table (2) express something about nickel's binding force to the soil. The reduced adverse value of $\Delta \mathrm{H}$ in the $\mathrm{S}_{2}$ than in the $S_{1}$ shows a greater binding of $\mathrm{Ni}^{2+}$ in $\mathrm{S}_{2}$ relative to $\mathrm{S}_{1}$. The variance in the binding strength of $\mathrm{Ni}^{+2}$ ions in both soils may be linked directly to differences in the external surface to interlayer surface charge ratio associated with the increase of clay content and organic matter in this soil. Increasing the clay content in $S_{2}$, indicating for the former a lower external surface to interlayer charge ratio. The rate coefficients of reactions and activation energies in Table (2) indicate that a partial collapse of the clay minerals is likely to occur in the $\mathrm{S}_{2}$ soil in the presence of $\mathrm{Ni}^{2+}$ ions. The lowering ratio between the external surface and interlayer surface- 
charge in the $\mathrm{S}_{2}$, greater binding of $\mathrm{Ni}^{2+}$ ions should be expected. This is illustrated by the decreasing of the exothermic $\Delta \mathrm{Ho}$ value of the $\mathrm{S}_{2}$ that $\mathrm{Ni}^{2+}$ exchange in the soils is an exothermic process, these results were in agreement with the results of Adamson (1973). Exothermic mechanisms are especially encountered in $\mathrm{Ni}$ exchange where electrostatic attraction forces are predominate (Filep and Khargitoan, 1977 and Kittrick, 1967). The $\Delta S^{\circ}$ values in used soils (Table $2 \&$ Figure 3 ) indicate greater (more favourable) entropy in the $S_{1}$ than in $S_{2}$. Since there is a substantial difference in clay in both studied soils, there may be more external and internal sites for $\mathrm{Ni}^{2+}$ reactions occurring in the greater clay content. For adsorption, there would be more methods for $\mathrm{Ni}^{2+}$ ions to distribute themselves refer to more sites for $\mathrm{Ni}$ adsorption in $\mathrm{S}_{2}$. Thus the solid component of $\Delta \mathrm{S}$ would enhance (Kuo and Lotse, 1974 and Diast and Talibudeen, 1967). Concerning desorption process, there would have been increasing of $\mathrm{Ni}$ desorption from the solid phase in $\mathrm{S}_{1}$ to the solution phase compared to that in $S_{2}$. This would likely from a higher rise in the solution component of $\Delta S^{\circ}$ in the $S_{1}$ relative to $S_{2}$. The parameter $\Delta \mathrm{G}$ represent is the variation in free energy needed for $\mathrm{Ni}$ to pass the barrier of adsorption at an obvious rate of $\mathrm{k}_{\mathrm{a}}$. This parameter reflects the variation in free energy required by the inverse reaction of desorption at the obvious rate of $\mathrm{k}_{\mathrm{d}}$. The distinction between these two parameters produces $\Delta \mathrm{G}$, the thermodynamic parameter formed from the equation of Gibbs. Although data are not shown, the comparison of these values to those computed from the equation demonstrates great agreement, suggesting that thermodynamic parameters can be calculated using a kinetic strategy. Also, in table 2 , the $\Delta \mathrm{G}$ values reflect the difference in free energy between the activated complex and the reactants, all substances remained in their standard states (Glasstone, et al., 1941 and Laidler, 1965). It is the value of $\Delta \mathrm{G}$ that assesses the reaction rate (Filep and Khargitoan, 1977). The $\Delta \mathrm{G}$ values for desorption were greater than for adsorption, indicating that Ni desorption needs large free energy. This would be well associated with reduced $\mathrm{k}_{\mathrm{d}}$ values and greater Ed values (Table 2). Also, the values of $\Delta G$ for both adsorption and desorption were also slightly greater in the $S_{2}$ than in the $S_{1}$ indicating slow reactions occurrence, due to the more binding sites for $\mathrm{Ni} 2+$ in the S2.

The $\Delta \mathrm{H}$ value measures the energy barrier that can be achieved by reacting the molecules (Glasstone et al., 1941). The $\Delta H$ values in the studied soils were lesser in adsorption than for desorption, implying that the heat energy needed to deal with the $\mathrm{Ni}^{2+}$ desorption barrier was higher than that for $\mathrm{Ni}$ adsorption. This was also shown in the magnitude of the values of $E_{a}$ and $E_{d}$ as found in Table (2). The $\Delta \mathrm{H}$ of adsorption reflects the change in heat energy required for $\mathrm{Ni}^{2+}$ to go from the solution phase to the solid phase, whereas $\Delta \mathrm{H}$ of $\mathrm{Ni}^{2+}$ desorption is the heat energy needed for the inverse process. The differences between these two parameters represent $\Delta \mathrm{H}^{0}$. The process of adsorption is an exothermic process which by it the heat is released, and the process of desorption is an endothermic reaction that by it the heat is adsorbed. This in agreement with Glasstone et al., (1941) conclusions that ion adsorption was obviously exothermic while desorption was always endothermic. Since the total $\Delta \mathrm{H}^{0}$ of the reaction is negative as shown in Table (2), Ni exchange is not an energy consuming mechanism. The entropy parameter is usually used to estimate the point of energy width (Jencks, 1969; Moreale and van Bladel, 1979). This parameter indicated that the molecules reaction must move as complexes with activation energy. Thus $\Delta \mathrm{S}$ transmits if a specific reaction proceeds quickly or slowly than another reaction individually takes place. It should be mentioned that the kinetics of adsorption were quicker than the kinetics of desorption, a more highly ordered system could be acquired with adsorption than with desorption. This is observed in the slightly larger negative values of $\Delta \mathrm{S}$.

\section{CONCLUSION}

Temperature has a significant and often ignored parameter in the fate and transport of pollutants in the environmental soil ecosystems. Temperature trails are quite essential to establish complete functioning models that allow investigators to better identify the movement and bioavailability of pollutants in soils. For most reactions, increasing the rate with increasing temperature is nonlinear. Nickel sorption was examined on alluvial soils varied in their properties at temperature degrees 5,28 and $50^{\circ} \mathrm{C}$ to calculate the first-order parameters and other thermodynamic parameters. The data in this work will be useful in developing inclusive models that describe sorption/desorption reactions affected by temperature and possible conditions of pollutant reactions in the alluvial soil environment.

\section{REFERENCES}

Adamson, A. 1973.A Text Book of physical chemistry. Academic Press, New York.

Aigberua, A.O. 2018. Soil organic matter: application for heavy metal source diagnostics in sediments of the Middleton River, bayelsa state, Nigeria. MOJ Toxicol. 2018;1 (4):410-415. 
Antoniadis, V., S.M. Shaheen, J. Boersch, T. Frohne, G. Du Laing and J. Rinklebe. 2017a.Bioavailability and risk assessment of potentially toxic elements in garden edible vegetables and soils around a highly contaminated former mining area in Germany. J. Environ. Manag. 186: 192200.

Antoniadis, V., E.E. Golia, S.M. Shaheen and J. Rinklebe. 2017b. Bioavailability and health risk assessment of potentially toxic elements in Thriassio Plain, near Athens, Greece. Environ. Geochem. Health 39: 319-330

Appel, C. and L. Ma. 2002.Concentration, pH, and surface charge effects on cadmium and lead adsorption in three tropical soils. J. Environ. Qual. 31: 581-589

Burns, A.F. and S.A. Barber. 1961.Effect of temperature and moisture on exchangeable potassium. Soil Sci. Soc Am. Proc. 25: 349-352.

Denbigh, K.G. 1966.The principles of chemical equilibrium: with applications in chemistry and chemical engineering. Cambridge U.P. (Cambridge)

Diast, J. and O. Talibudeen . 1967. Ion exchange in soils from ion pairs, K·Ca, K·Rb and, K·Na. J. Soil Sci. 18:125·137

Filep, D. and I. Khargitoan. 1977.Thermodynamic analysis of cation exchange processes in the soil solution system. Soviet Soil Sci. 9: 599-609.

Glasstone, S.K., J. Laidler and H. Eyring. 1941.The Theory of Rate Process. McGraw-Hill, New York.

Gimeno-García, E., V. Andreu and R. Boluda. 1996. Heavy metals incidence in the application of inorganic fertilizers and pesticides to rice farming soils. Environ. Pollut. 92: 19-25.

Jencks, W.P. 1969.Catalysis in Chemistry and Enzymology. McGraw-Hill, New York.

Kabata-Pendias, A. 2011.Trace Elements in Soils and Plants. Fourth Edition, CRC Press, Taylor \& Francis Group.

Kittrick, J.A. 1967.Gibbsite -kaolinite equilibria: Soil Sci Soc. Am Proc. 31: 314-31.

Kopittke, P.M., C.J. Asher, and N.W. Menzies. 2007. Toxic Effects of Ni2+ on Growth of Cowpea (Vigna unguiculata).Plant Soil 292:283-289.

Kuo, S. and E.G. Lotse. 1974. Kinetics of Phosphate Adsorption and Desorption by Hematite and Gibbsite. Soil Science 116:400-406.

Laidler, K. J. 1965. Chemical kinetics. Mac Graw-Hill. NewYork.

MA, Y. and P.S. HOODA. 2010.Characteristics and Behaviour of Individual Elements, Chromium, Nickel and Cobalt. In: HOODA, P. S. (ed.) Trace element in the soils. John Wiley and Sons, Ltd., London pp. 461-475.

McBride, M.B. 2000 Chemiadsorption and Precipitation Reactions, In: M.E. Sumner (Ed.), Handbook of Soil Science. CRC Press. Boca Raton. FL. pp. B265-B302

Marschner, H. 1995.Mineral Nutrition of Higher Plants. Academic Press, London.

Moore, W.J. 1972.Physical chemistry. $2^{\text {nd }}$ edition. Prentice Hall, Englewood Cliffes, n. J.
Moreale, A. and B. R. Van. 1979. Soil interactions of herbicide-derived aniline residues: a thermodynamic approach. Soil Sci. 127:1-9.

Mortland, M.M. and B.G. Ellis. 1959. Release of fixed potassium as a diffusion controlled process. Soil Sci. Soc. Am. Proc. 23:363-364.

Nadia, G., A. Zaghloul, L.S. Kozhamzharova, 123 G.K. Akhauova, G.A. Mukanova, B.M. Tynybekov. 2013.Thermodynamics of Cobalt Exchange in Soil Using Kinetic Approach. World Applied Sciences Journal 25 (4): 637-643.

Ogwada, R.A. and D.L. Sparks.1986. Use of mole or equivalent fractions in determining thermodynamic parameters for potassium exchange in soils. Soil Sci. 141:268-273.

Rajkumar, M. and H. Freitas.2008. Influence of metal resistant-plant growth promoting bacteria on the growth of Ricinus communis in soil contaminated with heavy metals. Chemosphere 71: 834-842.

Saber M, E. Hobballa, S. El-Ashery and A.M. Zaghloul. 2012. Decontamination of Potential Toxic Elements in Sewaged Soils by inorganic Amendments. J. Agricultural Sci. Technology A 2(11):1232-1244.

Sander, M., Y.F. Lu and J.J. Pignatello. 2005. A thermodynamically based method to quantifytrue adsorption hysteresis. J. Environ. Qual. 34: 1063-1072.

Scheidegger, A.M., G.M. Lamble and D.L. Sparks. 1996. Investigation of $\mathrm{Ni}$ sorption on pyrophyllite: an XAFS study; Environ. Sci. Technol. 30: 548-554.

Scheidegger, C., B. Frey and J.C. Walser.1998.Reintroduction and augmentation of populations of the endangered Lobaria pulmonaria: Methods and concepts. In: Lobarion Lichens as Indicators of the Primeval Forests of the Eastern Carpathians. (Darwinian International Workshop), pp. 33-53. Kostrino, Ukraine.

Sherine, S. and A. M. Zaghloul. 2014. Effect of Pollution Source on Distribution of Some Potential Toxic Elements in Different Soil Systems. International Journal Of Environment, 3(1): 16-25.

Sparks, D.L., L.W. Zelazny and D.C. Martens.1980.Kinetics of potassium exchange in a Paleudult from the Coastal Plain of Virginia. Soil Sci. Soc. Am. J. 44:37-40.

Sparks, D.L. 1995. Kinetics of metal sorption reactions. P. 3558. In H.E. Allen, C.P. Huang, G.W. Bailey, and A.R. Bowers (eds.) Metal speciation and contamination of soil. Lewis Publishers, Chelsea, Michigan.

Strawn, D.G. and D.L. Sparks. 1999.Adsorption kinetics of trace elements in soils and soilmaterials, in: H.M. Selim \& I. Iskandar (Ed.), Fate and Transport of Heavy Metalsin the Vadose Zone., Lewis Publishers, Chelsea, MI, pp. 128

Thakali, S., H.E. Allen, D.M. Di Toro, A.A. Ponizovsky, C.P. Rooney and F.J. Zhao. 2006. A terrestrial biotic ligand model. 1. Development and application to $\mathrm{Cu}$ and $\mathrm{Ni}$ toxicities to barley root elongation in soils. Environ Sci Technol 40: 7085-7093. 
Weber, W.J., W. Huang and H. Yu. 1998. Hysteresis in the adsorption and desorption of hydrophobic organic contaminants by soils and sediments: 2. Effects of soil organic matter heterogeneity, J. Contam. Hydrol. 31: 149165.
Yusuf, M, Q. Fariduddin, S. Hayat and A. Ahmad. 2011. Nickel: an overview of uptake, essentiality and toxicity in plants. Bulletin of environmental contamination and toxicology, New York. v. 86. n. 1. p: 1-17.

\section{الملخص العربي}

\section{تأثير نظم درجات الحرارة على حركيات النيكل فى أرضين طينتين من مناطق جاف لفريف}

سحر محمد إسماعيل ، شيرين شحاته مريد ، علاء زغلول

و Eyring ان الطاقة الحرة لتبادل النيكلهG كانت ذات قيم

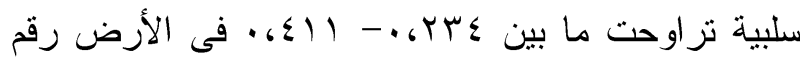

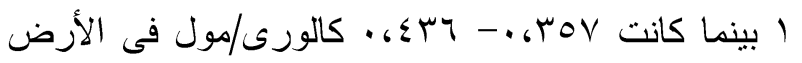

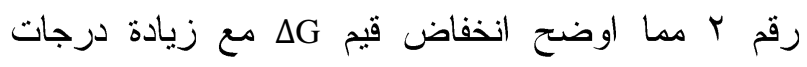

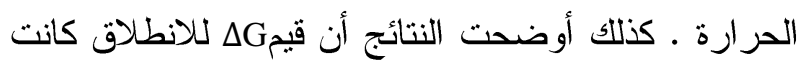

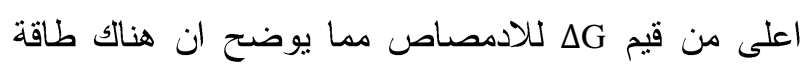

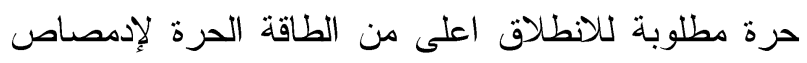

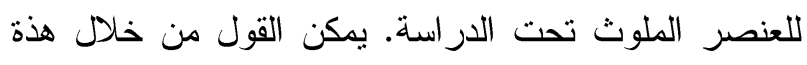

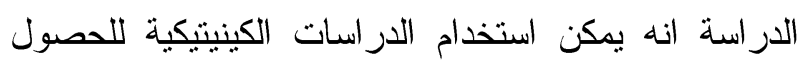

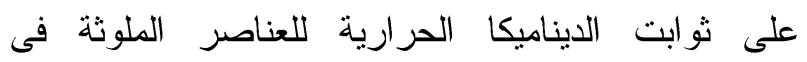

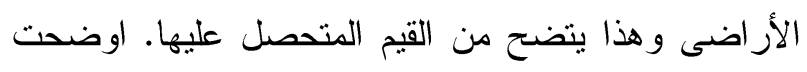

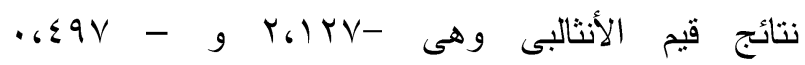

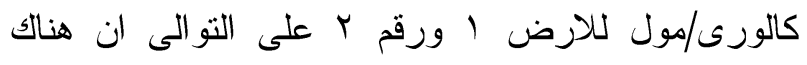

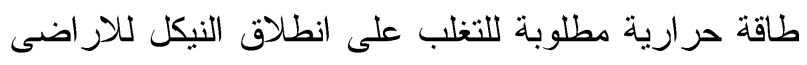

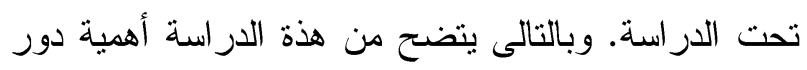
الحرارة فى التفاعلات الكيماوية المختلفة للعناصر الملوثة التى تضاف الى التربة.
اهتمت هذه الدراسة بنوضيح تفاعلات النيكل تحت تأثير

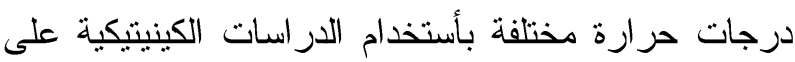
نوعين من الأراضى المصرية الطينية التى تم جمعها من اراضى دلتا النيل (المنوفية) مختلفة فى محتو اها من الطين والخواص الأخرى المرتبطة بهذا الأختلاف. أوضحت فيت الهن النتائج المتحصل عليها من الدراسات الكينيتيكية لادمصاص الاصني

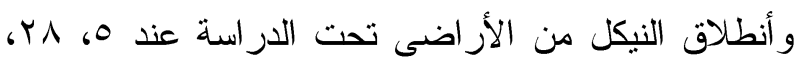

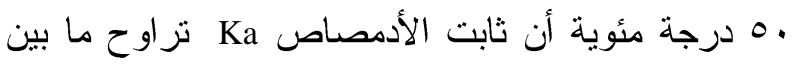

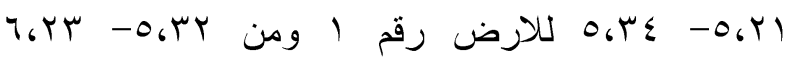

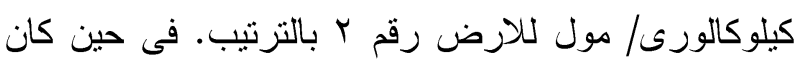

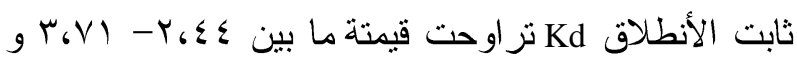

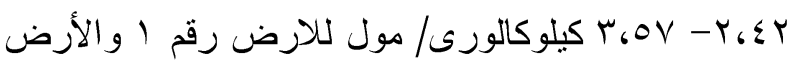

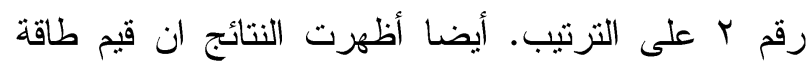

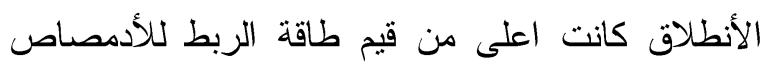

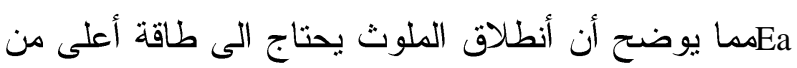

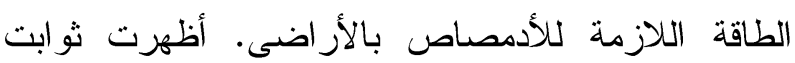

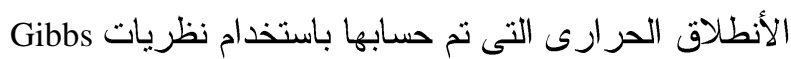

